\title{
Cultural Presentation in Thai Secondary School ELT Coursebooks: An Analysis From Intercultural Perspectives
}

\author{
Athip Thumvichit \\ Correspondence: Athip Thumvichit, Department of Curriculum and Instruction, Faculty of Education, Ramkhamhaeng \\ University, Bangkok, Thailand.
}

Received: August 13, 2018

doi:10.11114/jets.v6i11.3533

\author{
Accepted: September 12, $2018 \quad$ Online Published: September 16, 2018
}

URL: https://doi.org/10.11114/jets.v6i11.3533

\begin{abstract}
Globalization has accelerated the growth of English and created a need for several changes in English language teaching (ELT), one of which is related to the role of ELT materials in facilitating interaction across cultures. Considering the fast growing importance of cultural content in ELT, this study explores issues of cultural presentation in Thai secondary school ELT coursebooks. The purpose of this study is twofold: first, to analyze cultural content presented in visuals and reading texts; second, to investigate teachers' attitudes toward cultural presentation in ELT coursebooks. The coursebook sample included seven approved ELT coursebooks entitled Bridge 1, English in Mind 1, Messages 1, Motivate! 1, New World 1, Time Zone 1, and Your Space 1. The findings suggested that native speakers' contexts were dominantly portrayed in both visuals and reading texts in all the coursebooks except Time Zone 1, which yielded a great deal of non-native speakers' contexts. Nevertheless, Thai cultural context was completely absent from the reading-focused activities, and only a few pictures presenting Thai culture were identified. The questionnaire findings revealed that Thai secondary teachers are ready to embrace the intercultural aspects of ELT, as the overwhelming majority of respondents' opinions signified the shift toward localized and culturally diversified materials.
\end{abstract}

Keywords: English language teaching, cultural presentation, coursebook analysis, intercultural communication, secondary education

\section{Introduction}

The fast growing trend of globalization confirms the need for cultural content in foreign language lessons. In this regard, the models of English as a Foreign Language (EFL) and English as a Second Language (ESL) are gradually fading away and are being replaced by English as an International Language (EIL) which takes into account the cultural contexts of non-native speakers (Farzaneh et al., 2014). Backed up by many scholars, this new model touches on cross-cultural (Baxter, 1980; Smith, 1983), multicultural (Stern, 1992), intercultural (Smith, 1983), and universal (Crystal, 1992) dimensions of English.

Coursebooks play a key role in English language teaching (ELT) as they are often taken as the only reliable source of reference points for teachers and learners. Being regarded as a main teaching tool, coursebooks make the study of language more systematic, so learners can easily process it. Nevertheless, the issue of the 'globality' of ELT coursebooks has been raised by advocates of globalism in ELT (e.g., Sherman, 2010; Melliti, 2013; Vettorel \& Lopriore, 2013; Hanashiro, 2016). Melliti (2013) asserts that the globalizability of the coursebooks should be taken into serious consideration, not only in term of themes but also learners' identities. That is, without promoting cultural diversity and learners' identity, learners may be disconnected from the learning process as they cannot feel the value of learning. Such issues arose simply because learners are barred from exposure to a wide variety of culture and their identity through ELT coursebooks which, most of the time, only present and promote the culture of native speakers. Teachers and learners in Expanding Circle countries, one of Kachru's (1992) Three Concentric Circles (e.g., Japan, China, South Korea, Thailand), are likely to encounter culturally biased ELT coursebooks, as they tend to overlook their local contexts and intercultural communication, and abide nativism.

The impact of the application of culturally appropriate materials was studied extensively by McKay (2003) who posits that they pedagogically and linguistically influence the learning process. In the former case, cultural contents are taken into account when designing or selecting materials, leading to the reduction of cultural bias. The latter influences the growth of semantic, pragmatic, and discourse competences of learners. It is important to keep in mind that one of the primary purposes of EIL is to ease communication between non-native speakers, who constitute the vast majority of the 
users of English. In this sense, material developers and even teachers should design and select materials that promote intercultural communication in order to jump on the bandwagon of the fast moving globalization trend and improve foreign language teaching and learning.

In Thailand, English is not used as an official language nor as a lingua franca, but rather it is considered just one of the widely-used foreign languages. Despite the fact that it is a compulsory subject in primary, secondary, and even tertiary education, the English proficiency level of Thai people is relatively low compared with other members of the Expanding Circle. The country was ranked $53^{\text {rd }}$ which is much lower than countries like Vietnam $\left(34^{\text {th }}\right)$, China $\left(36^{\text {th }}\right)$, and Japan $\left(37^{\text {th }}\right)$ (Education First, 2017). This implies that English education in Thailand has failed to keep up with the demands of globalization, although education reforms were introduced back in 1999. As part of the reforms, the use of English as a medium of instruction was proposed in order to accelerate internationalization of education. In 2008, the 2001 Basic Education Curriculum (BEC), which had served as the curriculum design framework for basic education nationwide, was revised in response to the objectives of the 1999 National Education Act (NEA) and Second Nation Education Act (SNEA) implemented in 2002. The 2008 Basic Education Core Curriculum (BECC) aims to prepare students for the rapidly changing global economy, technology, and social transformations (Kaur et al., 2016). As for foreign language learning, apart from an emphasis on building communicative competence and positive attitudes toward the target language, BECC also focuses on the cultural aspects of language education as follows:

Foreign languages enable learners to be aware of diversity of cultures and viewpoints in the world community, conducive to friendship and cooperation with various countries. They contribute to learners' development by giving learners better understanding of themselves and others.

(Ministry of Education, 2008, p. 252)

This can be interpreted that school teachers are encouraged to promote awareness of cultural diversity, and cross-cultural communication should be emphasized in the classrooms. This aspect of foreign language teaching and learning strives to internationalize and lift up educational standards to meet the demands of globalization.

By investigating cultural aspects of ELT coursebooks, this study is committed to promoting cultural diversity in ELT, as stated in the 2008 BECC, and the use of English as a medium of intercultural communication. The purpose of this study is to investigate whether secondary school ELT coursebooks approved by the Ministry of Education deliver sufficient cultural elements for students to achieve intercultural communication in the target language. This study touches on two areas of coursebook evaluation - cultural content and teachers' attitudes. Three questions are proposed as follows:

1) To what extent is cultural diversity presented in ELT coursebooks used in Thai secondary schools?

2) Is there any difference between ELT coursebooks used in Thai secondary schools in term of cultural content?

3) What are Thai secondary school teachers' attitudes toward the presentation of culture in ELT coursebooks?

\section{Literature Review}

\subsection{EIL}

Since language and culture cannot be separated, apart from functioning as a systematic means of communication and transmission, language also serves as a carrier of human culture. Every communicative activity always delivers some, if not all, of the aspects of a culture (Kaplan, 1983). Vygotsky (1986) notes that language and culture are interrelated. In the globalization era, communication between people from different parts of the world is no longer rare. Although the interaction can easily take place, regardless of where interactors are, the issues of cultural awareness will be raised. It is suggested that no matter what language individuals use as a means to communicate they are aware of cultural differences (İşcan et al., 2017). In this regard, individuals should take into account the culture and context of interlocutors.

Globalization has made English the world's language, as it has been regarded as a lingua franca, a bridge language connecting people across the globe. One cannot deny that globalization has affected the way English is used, especially for intercultural communication. Technological advancement and population growth have also contributed to the internationalization of English. As a result, there has been a rapid growth in interaction between English and other languages, and English is excessively used in different communities across the globe (Monfared et al., 2016). Making a timely response to the widespread global usage and evolution of English, Kachru (1992) divided the world into three Concentric Circles: Inner Circle, Outer Circle, and Expanding Circle (see Figure 1). Inner circle comprises countries where English is dominantly used and considered as the first and primary language of the country (e.g., UK, USA, Australia, and New Zealand); and thus, the majority of people in these countries are automatically viewed as native speakers of English. In these countries, English is acquired primarily through socialization (Suzuki, 2007). English is in their daily lives and made appropriate for their native communities. The estimated number of speakers of English in the 
Inner Circles is between 320 and 380 million (Crystal, 2003).

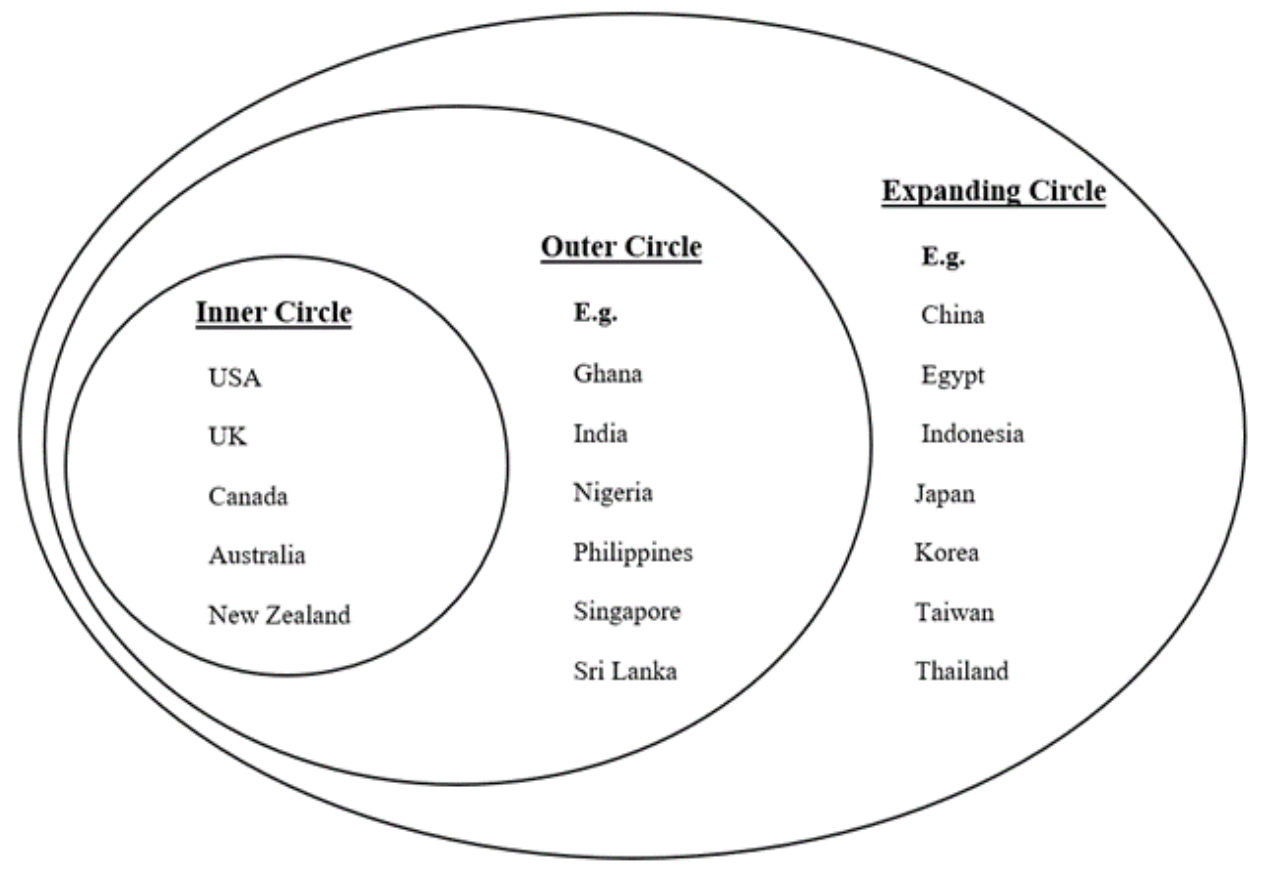

Figure 1. Kachru's Concentric Circles of English (Kachru, 1992)

Outer Circle countries refer to the formerly colonial countries where English is used as a second language (e.g., India, Malaysia, Philippine, Singapore). Although English is not the native language of the countries, it plays an increasingly important role as a second language (ESL). English is acquired in addition to their mother tongues. Despite holding the status of a second language, English is widely used and well accepted for purposes such as academics, laws, and government.

English has even been further pluralized. The countries where English is used as another foreign language are considered members of the Expanding Circle where English serves limited purposes within their territories. This circle includes, but is not limited to, China, Japan, Korea, Taiwan, and Thailand. In the Expanding Circle, English is perceived as 'norm-dependent' as they abide by the standards set up by native speakers.

The World Englishes (WEs) model was developed to promote the existence of English varieties which cover different types of speakers of English ranging from native speakers by birth to those with very limited use of English in day-to-day lives (Saengboon, 2015). This does not mean that its full attention is paid to the distinction of linguistic elements; WEs also deals with intelligibility, identity, and teaching and learning. Pedagogically speaking, ELT can be put into two main categories based on the geographical regions - Teaching English as a Foreign Language (TEFL) and Teaching English as a Second Language (TESL). TEFL takes place in non-English speaking regions where English is taught as part of the school and university curriculum. Such term is widely used in Thailand as English is one of the compulsory subjects, despite the fact that it is not used in students' daily lives. As for the English-speaking countries, the terms TESL and ESL tend to be more recognizable. Teaching English in English-speaking countries always involves refugees and immigrants, as it helps them survive in the country. ESL students tend to get exposed to the language in their everyday lives, which undoubtedly accelerates their growth in language proficiency.

The emergence of such terminologies has led scholars, particularly in the field of ELT, to the debate on pedagogical options and the variety of English that should be prioritized. Although American and British English are known to be the only dominant language globally, the growing importance of intercultural communication is bringing changes to English classrooms and alternatives for teachers. Considering varieties of English, cultural differences, and identities of learners, the concept of EIL sheds some light on the future of English language teaching and learning, especially in non-English speaking countries. There is a recent call from sociolinguists for the introduction of EIL into ELT classrooms (Matsuda, 2003). It is argued that experiencing different varieties of English not only develop learners' communicative skills, but also create awareness of successful interactions, which do not depend solely on the rules of languages (Suzuki, 2010). However, before jumping into the implication, Matsuda (2009) stresses that teachers' understanding of varieties of English and the nature of intercultural communication are important; and thus, preparation 
is required. In reality, teachers are not the only group of people who plays a crucial role in the instruction; material developers also hold the key to this success as their products are usually used as a reference point.

\subsection{Roles of Coursebooks in ELT}

The use of coursebooks makes students believe that learning is taken seriously, and for students, it is considered an effortless way of language learning (Ansary \& Babaii, 2002). It is also considered less time-consuming for teachers compared with using in-house materials developed by the teachers themselves (Garinger, 2002). There is no doubt that coursebooks have made their way to become much more than expected. Cortazzi and Jin (1999) asserts that coursebooks can even play the role of a teacher, an authority, and a provider of ideology.

Despite being praised for crucial roles they play in language education, coursebooks have been criticized by researchers. Cunningsworth (1995) demonstrates four main drawbacks of coursebooks: a lack of variety of pedagogical procedures, limited opportunity for innovation toward individual goals, insufficient flexibility and spontaneity, and limited instructional approaches and language use. It is important to keep in mind that overreliance on coursebooks can diminish the value of individual contributions (Cunningsworth, 1995). This, however, does not mean that coursebooks have no place in ELT. A well-developed coursebook with room for adaptation should still be considered. The coursebook industry has expanded rapidly over the past decade. Since there are a handful of selections available on the market, targeting various levels of learners and responding to different institutional needs, it is still important to use certain guidelines to help teachers select the most effective coursebooks for their contexts.

\subsection{Cultural Content in ELT Coursebooks}

There is no doubt that ELT coursebooks can influence the way learners perceive culture and language. In the globalization era, ELT coursebooks play a crucial role in transferring cultural and linguistic knowledge, especially under the circumstance in which learners have very limited exposure to the language in daily life. Thai learners, for example, rarely use English outside of schools. The absence of English in their day-to-day lives adds value to the coursebooks, which gives them the opportunities to be exposed to the language and culture. ELT coursebooks are considered to be the main sources of linguistic and foreign culture knowledge (Bardovi-Harling, 1996). Such phenomenon has urged ELT material developers to produce coursebooks that promote cross-cultural communication as they can shape learners' perceptions toward the world of English and brings awareness to the classroom. Monfared et al. (2016) suggest that ELT materials should present the world of English where cultures are blended in the way that learners can relate their local contexts to the different cultures presented in the coursebooks. ELT coursebooks should now be designed in the way that they represent a multitude of cultures and encourage learners to realize the existence of other cultures in the world of English. Matsuda (2012) notes that cultural content in general ELT coursebooks should be diversified. That is, material developers are suggested to gather cultural content from various sources in order to project true multiculturalism. The discussion section, for example, in ELT coursebooks, may include topics such as international cuisine, worlds' historical sites, and cultural diversity in education. The topics have the potential to boost cultural awareness among learners and bring cultural diversity into the classroom. Cortazzi and Jin (1999) propose three types in which culture in ELT coursebooks can be analyzed: source culture; target culture; and international target culture.

The source culture refers to learners' cultures. In some countries, the local context is much more preferred than native speakers' cultures when it comes to ELT coursebooks. The rationale behind the selection of local content is to boost learners' awareness of their own identity (Cortazzi \& Jin, 1999). In this regard, such ELT coursebooks always present the topics that the learners are familiar with and the images that represent the learners' cultures (e.g., local cuisine, local places). Some examples of such ELT coursebooks include English for Saudi Arabia used in Saudi Arabia; Spot light on English used in Turkey; El libro de inglés used in Venezuela; and Comet English Communication used in Japan. These ELT coursebooks put an emphasis on source culture.

The target culture refers to the culture of England or America. There is no doubt that the vast majority of ELT coursebooks were designed based solely on this target culture. To the best of the researcher's knowledge, there have been only a few in-house publishers to feed the Thai national market; and thus, most of the ELT coursebooks approved to be used in schools are produced by external publishers. ELT coursebooks with an emphasis on the target culture are severely criticized for providing limited exposure to cultural diversity. The ELT coursebooks that focus on native speakers' cultures fail to address the local contexts and recognize English as a global language (Altan, 1995). Reflecting on the issues of cultural content in ELT coursebooks, Goldstein (2008) states that with the absence of global diversity, learners are likely to feel disconnected with the language, and the global communication is not facilitated.

The international target culture refers to a wide variety of cultures, regardless of the ownership of the language. Projecting characters from many different countries around the world, the ELT coursebooks promoting the international target culture strive to develop learners' intercultural communicative competence (Siddiqie, 2011). This type of ELT 
coursebook receives tremendous attention from scholars as it presents the language in various contexts and promotes global interaction. That is, the material developers may present topics of different cultures; and thus, learners can experience other cultures through English language learning.

\section{Methods}

This study was divided into two parts: first, the selected ELT coursebooks were analyzed and discussed with cultural perspectives; second, a questionnaire was used to investigate teachers' attitudes toward cultural presentation in ELT coursebooks.

\subsection{Part I: Materials}

This study analyzed the secondary school ELT coursebook series entitled Bridge, English in Mind, Messages, Motivate!, New World, Time Zone, and Your Space. The choice of the coursebooks was based on availability and recommendations from teachers. Approved by the Ministry of Education, these series are designed specifically for ESL and EFL contexts. The first coursebook of each of the series was chosen for the analysis (see Table 1). To address the first two research questions, the researcher looked into two different domains: visuals and reading texts.

Table 1. Coursebook sampling

\begin{tabular}{|c|c|c|c|}
\hline Title & Author & Publisher & Level \\
\hline Bridge 1 & Adams et al. & Heinle Cengage Learning & $\begin{array}{l}\text { Mathayom } 1^{1} \\
\text { (Grade } 7^{\text {th) }}\end{array}$ \\
\hline English in Mind 1 & Puchta \& Stranks & Cambridge University Press & Mathayom 1 \\
\hline Messages 1 & Goodey \& Goodey & Cambridge University Press & Mathayom 1 \\
\hline Motivate! 1 & Heyderman \& Mauchline & Macmillan Education & Mathayom 1 \\
\hline New World 1 & Santos & McGraw Hill Education & Mathayom 1 \\
\hline Time Zone 1 & Collins \& Maples & $\begin{array}{l}\text { National Geographic/Heinle } \\
\text { Cengage Learning }\end{array}$ & Mathayom 1 \\
\hline Your Space 1 & Hobbs \& Keddle & Cambridge University Press & Mathayom 1 \\
\hline
\end{tabular}

\subsubsection{Visuals}

In order to investigate the cultural presentation in both visuals and reading texts in ELT coursebooks, Cortazzi and Jinn's (1999) analytical framework was adopted and adjusted for the purpose of the present study, as their framework concerns various types of cultural content in ELT coursebooks. The pictures were divided into four different categories based on the cultural references they depicted: Picture with target culture reference (PTCR); Picture with source culture reference (PLSR); Picture with international culture reference (PICR); and Picture with culture free reference (PCFR) (see Table 2).

Table 2. Coding scheme for analyzing cultural presentation in visuals

\begin{tabular}{ll}
\hline Code & Description \\
\hline PTCR & $\begin{array}{l}\text { The picture that has references to the culture belonging to any of Kachru's (1992) } \\
\text { Inner Circle countries }\end{array}$ \\
\hline PSCR & The picture that has references to Thai culture \\
\hline PICR & $\begin{array}{l}\text { The picture that has references to the culture belonging to any of Kachru's (1992) } \\
\text { Outer and Expanding Circle countries, with the exception of Thailand }\end{array}$ \\
\hline PCFR & The picture that has no reference to any particular culture \\
\hline
\end{tabular}

The preliminary observation of the coursebooks shows that the reference of cartoon pictures is very ambiguous as they do not provide enough detail for the researcher to identify their references. In this regard, only photographs (pictures of real people, animal, and objects) were drawn from the coursebooks for the analysis. When there was difficulty in identifying the category of the picture, the descriptions (e.g., name, nationality) located near the pictures were also used to support the interpretation.

\subsubsection{Reading Texts}

The rationale behind the choice of reading texts is that they tend to contain cultural content (Adaskou et al., 1990). Reading texts were collected from reading activities which are available in each unit of the coursebook sample, and they were analyzed based on the cultural references they contain. The data were categorized into Reading text with target culture content (RTCC), Reading text with source culture content (RSCC), Reading text with international culture content (RICC), and Reading text with free cultural content (RFCC) (see Table 3). The indicators for cultural identification include ideologies, characters, customs, places, and terms pointing to certain cultures. In the case that both 
native and non-native speakers' cultures were presented in the same reading text, the researcher had to look into the 'power' of the presentation. For example, if non-native speakers are presented as tourists or visitors, the text will be labeled RTCC. On the other hand, if the identity of native speakers is not placed over that of non-native speakers, the text will be labeled RICC.

Table 3. Coding scheme for analyzing cultural presentation in reading texts

\begin{tabular}{ll}
\hline Code & Description \\
\hline RTCC & $\begin{array}{l}\text { The reading text that contains the content that refers to the culture belonging to any of } \\
\text { Kachru's (1992) Inner Circle countries }\end{array}$ \\
\hline RSCC & The reading text that contains the content that refers to Thai culture \\
\hline \multirow{2}{*}{ RICC } & $\begin{array}{l}\text { The reading text that contains the content that refers to the culture belonging to any of } \\
\text { Kachru's (1992) Outer and Expanding Circle countries, with the exception of Thailand }\end{array}$ \\
\hline RFCC & The reading text that contains the content that does not refer to any particular culture \\
\hline
\end{tabular}

To confirm the reliability of the coding, the researcher went through each picture multiple times to categorize the cultural contents. Additionally, an inter-rater reliability test was conducted to measure the degree of agreement between individuals. That is, another rater who has ample experience in coursebook evaluation and teaching English was invited to serve as an external rater. $25 \%$ of the total visuals and reading texts were randomly selected and assigned to the other coder for independent coding. Considering the categorical variables of the cultural contents, Cohen's Kappa, $\kappa$,

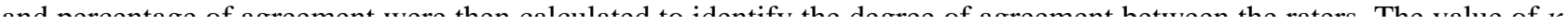
ranges from $0-1 ; \kappa=0$ implies that there is no agreement between coders, and $\kappa=1$ indicates that coders agree on every decision.

The results of $\kappa$ were .867 (visuals) and .848 (reading texts), both of which were 'almost perfect' (Landis \& Koch, 1977) or 'excellent' (Fleiss, 1981) (see Table 4). Thus, such figures imply strong reliability of the coding systems. ${ }^{2}$

Table 4. Results of inter-rater reliability tests

\begin{tabular}{lccc}
\hline & $\boldsymbol{\kappa}$ & Percentage of agreement \\
\cline { 2 - 4 } & Visuals & .867 & $92.5 \%$ \\
Reading texts & .848 & $91.1 \%$ \\
\hline
\end{tabular}

\subsection{Part II: Teachers' Attitude}

The second part concerns Thai secondary school teachers' attitudes toward cultural presentation in ELT coursebooks, which is considered the first step to promote intercultural communication in the classroom.

\subsubsection{Participants}

The participation requirements included: (1) holding a degree in a related field, (2) holding an upward of five years of teaching experience in secondary level, (3) holding Thai nationality, and (4) being a Thai L1 speaker. The selection of participants was based on accessibility. After the background screening, 30 qualified Thai secondary school English teachers were identified (see Table 5).

Table 5. The questionnaire participants' profile $(n=30)$

\begin{tabular}{cc}
\hline Profile & Number of participants \\
\hline Teaching experience in secondary level (years) & 19 \\
$5-10$ & 11 \\
More than 10 & \\
\hline Highest degree held & 24 \\
Bachelor's degree & 6 \\
Master's degree & 30 \\
\hline Nationality & \\
Thai & 30 \\
L1 & 30 \\
Thai &
\end{tabular}

\subsubsection{Questionnaire and Procedure}

A questionnaire was employed to find out Thai secondary school English teachers' attitudes toward cultural presentation in ELT coursebooks. Developed under the supervision of the research advisory panel, the questionnaire was constructed based on the purpose and scope of this study. There were two sections in the questionnaire: background 
information and perceptions toward cultural presentation in ELT coursebooks. The first section was used to confirm that the respondents met all the requirements before participating. In the second section, the questionnaire moves from general ideas about culture in ELT to more specific perspectives of cultural content in ELT materials. A set of questionnaires was distributed to the respondents $(n=30)$ and immediately collected after the completion. Thus, the return rate was $100 \%$.

\section{Results and Discussions}

\subsection{Cultural Content in Visuals}

As coding proceeded, it was discovered that pictures were not used for decorative purposes or as space-fillers, which concerns some researchers (e.g., Hill, 2013), but rather they are presented as pedagogical tasks. For instance, pictures were used in matching exercises where students were asked to match vocabularies with pictures. After several rounds of coding, the frequency counts of cultural units were identified. Pictures that contain no cultural value frequently appeared in the coursebook sample, especially in Bridge 1, Motivate! 1, New World 1, and Time Zone 1, where around half of the pictures had no reference to any culture in particular. Pictures of home appliances, vehicles, and fruits are great examples of PCFR identified in the coursebook sample, as they contain no reference to any culture in particular. On the other hand, this type of picture was not very common in English in Mind 1, Messages 1, and Your Space 1 with only $16 \%, 20.1 \%$, and $29.7 \%$ of the total pictures respectively.

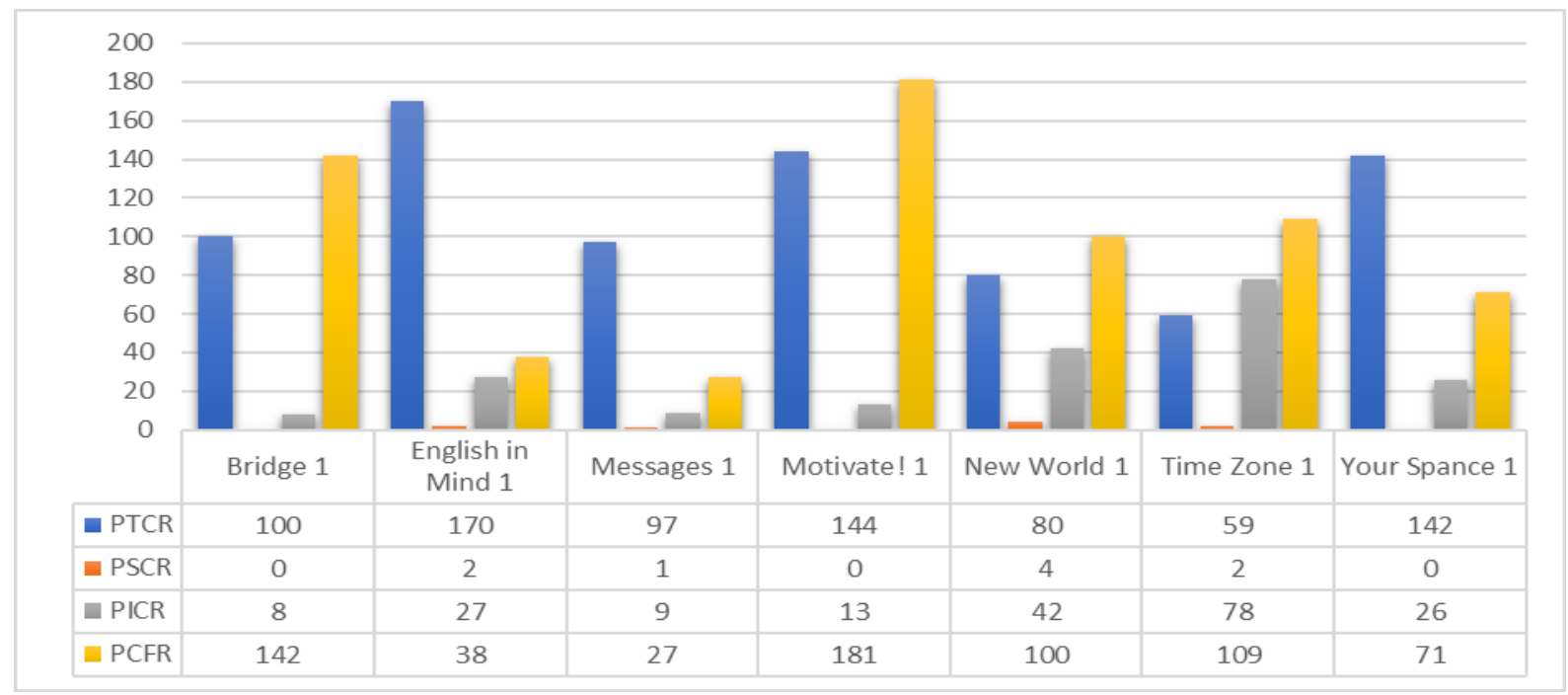

Figure 2. Frequency counts of cultural contents in visuals

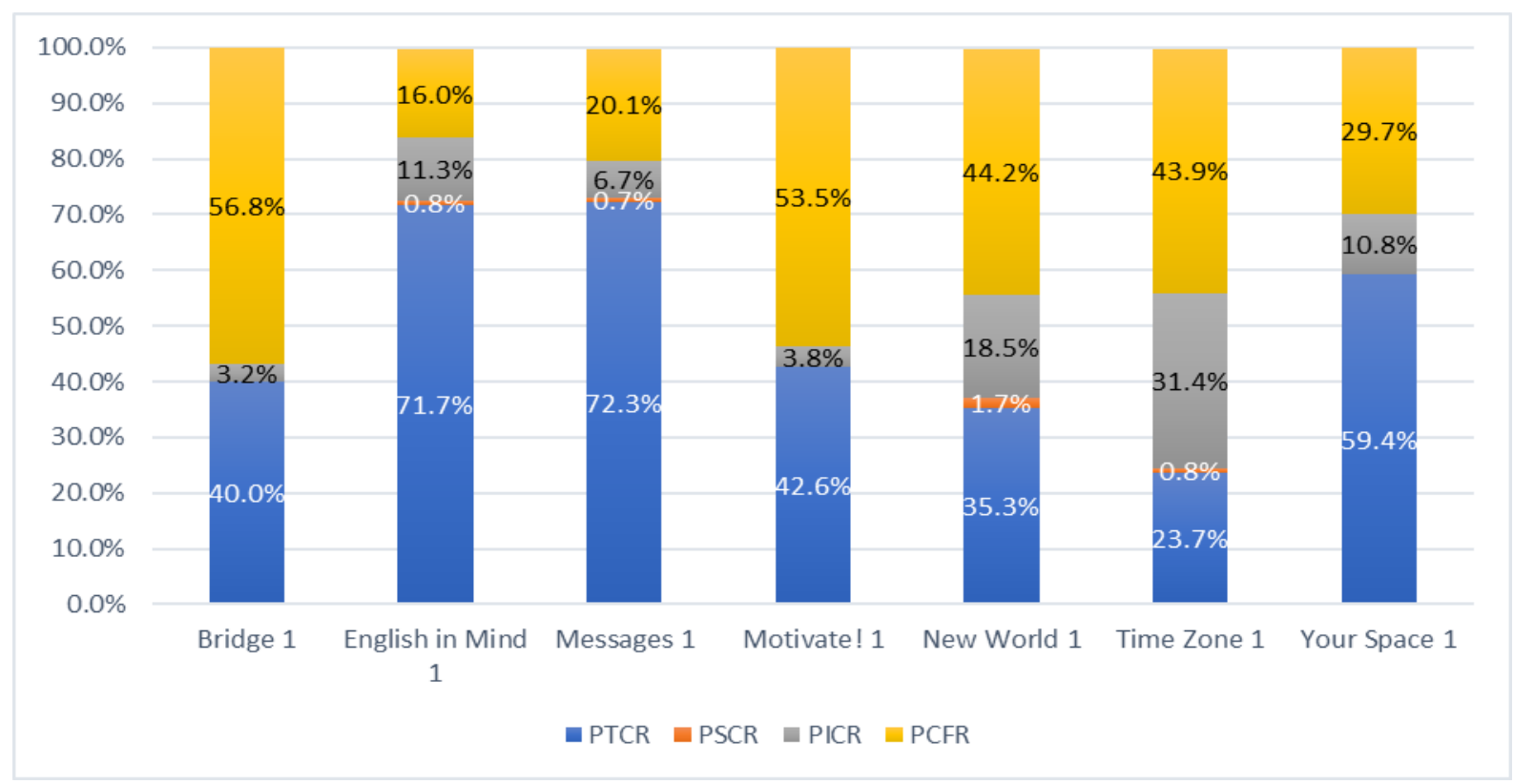

Figure 3. Proportion of cultural contents in visuals 
As for the target culture, pictures with Inner Circle countries' culture could easily be noticed in English in Mind 1, Messages 1, and Your Space 1 as they appeared much more frequently than the others, and constituted more than half of the total number of units identified. These coursebooks were found to employ a great deal of pictures of characters who were portrayed as native speakers of English, places (e.g., Museum of Science in Boston, Princeton University in Princeton, Blackpool Tower in Blackpool), and events (e.g., America's National Basketball Association match, Scotland's Highland Games, Liverpool's football match) in Inner Circle countries. Many times names (e.g., Ben, Joe, Lisa) and nationalities, along with people's pictures, were used to support cultural identification. In some cases, the pictures of objects could also have references to Inner Circle countries' cultures. An example is the picture of a London bus, which is one of the national icons. However, such portrayals were not overemphasized in Time Zone 1, with only $23.7 \%$ of the total pictures.

International culture seems to be under-presented in all the coursebooks except Time Zone 1 wherein PICR appeared more frequently than PTCR with 78 (31.4\%) units identified. It can be seen that the coursebook explicitly promotes a diverse range of nationalities through visuals. Visually speaking, unlike English in Mind 1, Messages 1, and Your Space 1 where the cultural presentation was dominated by the content related to Inner Circle countries, Time Zone 1 offers exposure to cultural diversity as it takes students on a journey around the world. With the illustrations of iconic destinations in Outer and Expanding Circles countries (e.g., Sagrada Familia Cathedral in Spain, Machu Picchu in Peru, Shinjuku's shopping street in Japan) students are given the opportunity to capture the real sense of globalization.

Nevertheless, pictures with references to Thai culture were extremely rare with only nine units identified in the coursebook sample. This leads to the conclusion that the material developers are not concerned about the students' culture and identity.

\subsection{Cultural Content in Reading Texts}

A total number of 135 reading texts were identified in the coursebook sample. It was found that different types of reading texts were employed for reading-focused activities such as letters, advertisements, dialogues, and descriptive and informative reading passages. A particular form of reading could be used in one, but not the other coursebooks. In English in Mind 1, for example, some reading activities involved dialogues rather than other types of reading texts. The applications of reading texts tend to vary from one to another. That is, reading texts were used for different activities such as simple question answering, paragraph matching, reflective reading, and true-false identification. In general, reading texts were identified in reading sections of each unit; but, some of them were used as supplemental reading presented in special sections. For example, Messages 1 provided supplemental reading passages in Extra Reading section placed between units.

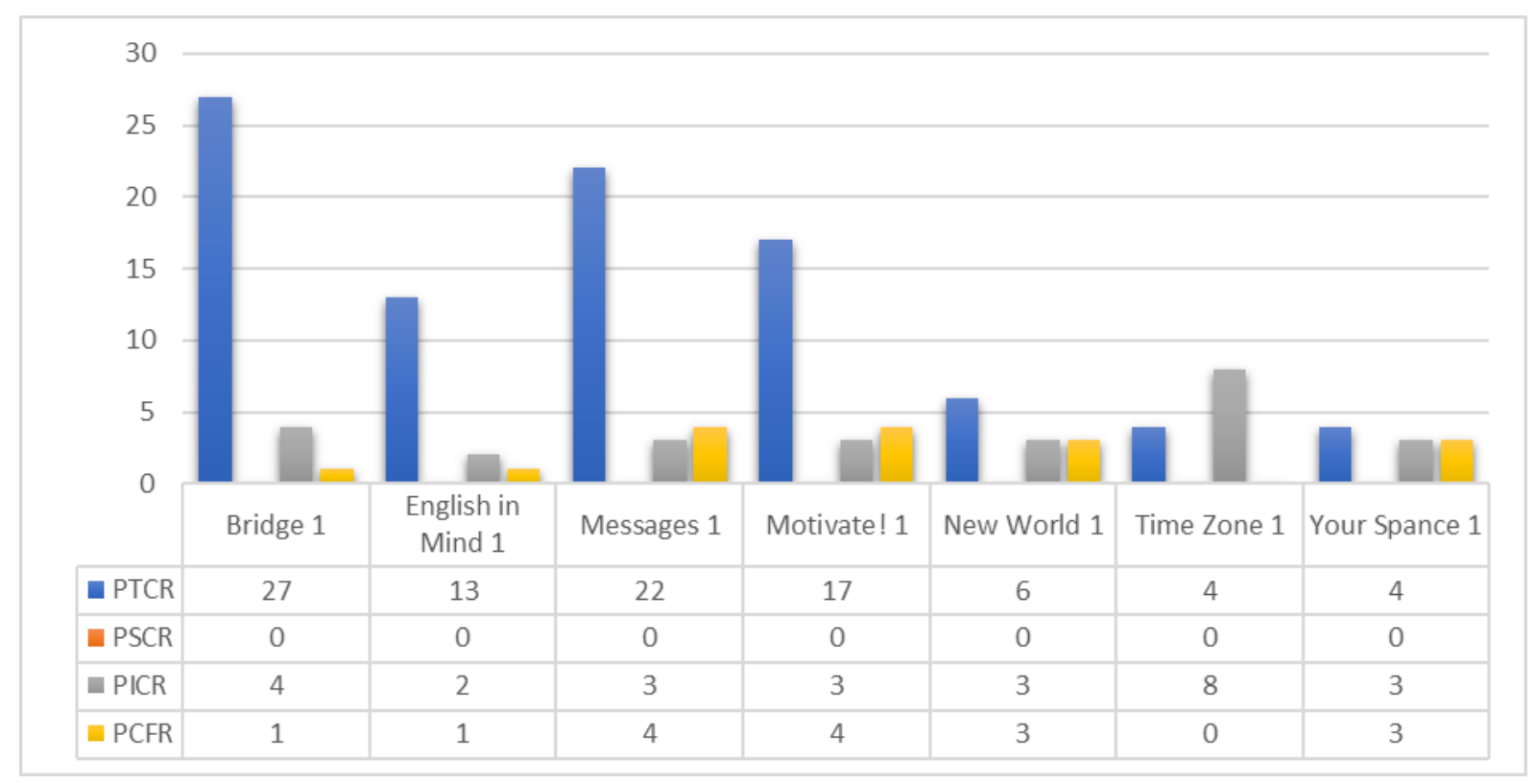

Figure 4. Frequency counts of cultural contents in reading texts 


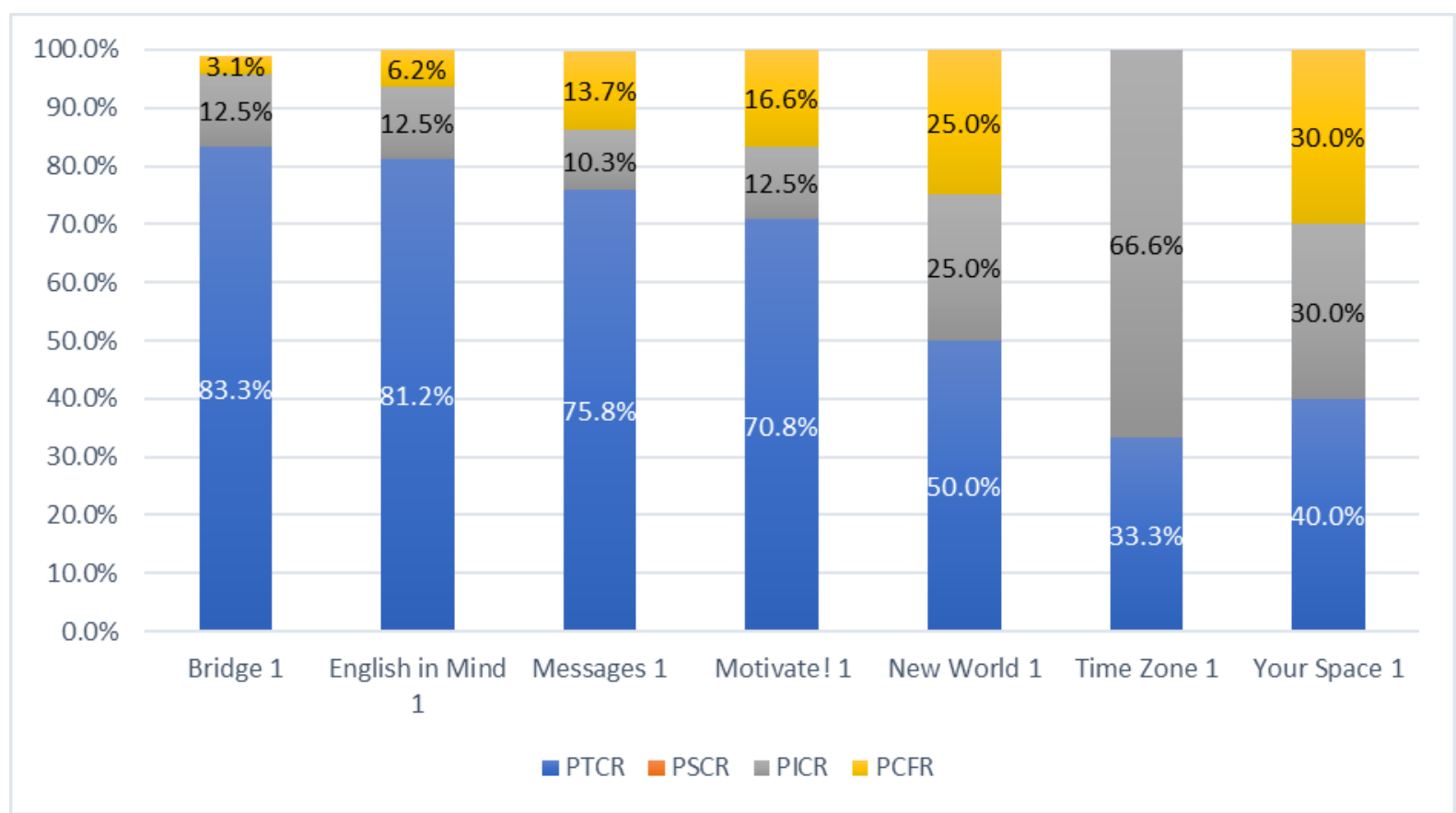

Figure 5. Proportion of cultural contents in reading texts

The findings indicated that when it comes to reading, the reading texts without an indicator to a particular culture were not frequently seen in the coursebook sample. This type of reading text was completely absent in Time Zone 1. However, in Your Space 1, 30\% of its reading texts contain no reference to a certain culture. The following extract is an example of RFCC.

The day starts at 9 am. You meet your teachers and get ready for sport! It's like an Olympic Village for teenagers! In the morning you choose a sport. And you do it for three hours. But there is lots of time to watch and learn. At lunchtime you can eat and chat with your new friends....

(Your Space 1, p. 66)

This extract was taken from the reading text entitled Sports4you. It had no specific cultural content hidden inside, as it only advertised a summer camp for children. The place called Olympic Village contains no reference to any culture in particular as there are many Olympic Villages which were used as accommodation centers for the Olympic Games. In this regard, such a term was not used as a cultural indicator.

The vast majority of the reading texts found in the coursebook sample had some sort of cultural values. The frequency counts presented here tend to align with the previous findings of cultural content in visuals. In Bridge 1, English in Mind 1, Messages 1, and Motivate! 1, the majority of their reading texts yielded contents that promote cultures of Inner Circle countries, with over 70\% of their reading texts; and thus, the context of Outer and Expanding Circle countries was rarely noticed. Similar findings could be seen in the case of New World 1 and Your Space 1 where RTCC was ranked number one, with $40 \%$ and $50 \%$ respectively. The text below is an example of RTCC.

I'm writing this email from a café across from Niagara Falls, and I'm drinking a glass of iced tea. The weather is sunny and warm. It's also windy, and I'm getting wet from water from the falls. Ron is taking pictures near the falls. There are many tourists here from different countries. The falls are amazing and beautiful - and they are really noisy! Well it's time for a boat ride under the falls. See you on Monday in Washington.

(New World 1, p. 67)

In the text, several key indicators were identified. Niagara Falls and Washington were among the indicators as they are located in Inner Circle countries. Considering the description of the Niagara Falls experience, the cultural content embedded in this text leaned toward the presentation of native speakers' culture; and thus, it was labeled RTCC. In some reading texts, Inner Circle countries' cultures were more explicitly presented as follows: 


\section{The $U K$}

Children go to school from Monday to Friday. They started school at the age of four or five and they leave at 16 or 18 . When they are 11, they go to secondary school....

\section{Australia}

Children begin school at the age of five. At the age of 11, they go to a high school for six years. Some students go to a special type of high school, for example, Agricultural High Schools and Sport High Schools....

\section{The USA}

Children start elementary school at six. When they are 12, they go to a Junior High School. At 15, pupils change to Senior High School where they can choose what they want to study....

(Messages 1, p. 57)

The reading texts above presented how children proceed in the fundamental systems of education of three different countries, all of which are the members of Inner Circle countries. It is obvious that these countries were chosen simply because they are the countries of native speakers of English.

However, in Time Zone 1, cultures of non-native speakers of English were frequently presented in reading texts. The figure of RICC was two times higher than that of RTCC. This implies that the developers of Time Zone 1 were strong-willed toward bringing cultural diversity into the classroom and were aware of intercultural communication in ELT. The extract below is an example of RICC.

Everyone loves carnival! It's the number one holiday in Brazil. Carnival is a four-day party in February or March. That's summer in Brazil, and the weather is hot. Carnival starts with the samba Parade....

(Time Zone 1, p. 87)

The writer chose Carnival, an annual festival in Brazil, as a reading topic. The event was described in detail, so students get some ideas how it is celebrated in Brazil. A passage like this takes students to different countries to explore cultural diversity. It also provides students with cultural knowledge which is acquired as students are practicing their reading skill. Sherman (2010) posits that cultural content embedded in reading texts have the potential to shape students' perspective and the way they perceive English. Presenting a wide variety of cultures through reading will promote intercultural communication regardless of cultural background. In Time Zone 1, the topics were built around various international themes which give students a global perspective of how English is used to express different cultural identities.

Nevertheless, Thai culture is completely absent from the reading texts of the coursebook sample even though some pictures with references to Thainess were identified in the visual analysis. Again, this implies that the material developers overlook the identity of Thai students. Gass and Selinker (2008) assert that a foreign language becomes easier to process when students are familiar with the contexts. In addition, the chance for students to be able to express themselves is slimmer without the value of students' identities in the lesson (Sherman, 2010).

\subsection{Teachers' Attitude Toward Cultural Presentation}

Once asked whether they found teaching a foreign language impossible without teaching culture (item 1), $80 \%$ of the respondents either agreed or strongly agreed, leaving only one disagreeing and five who could not decide (see Table 3 ). The term impossible in the statement may have been too decisive for some respondents who are not yet aware of the role of culture in ELT. Such figure was slightly decreased in the second item as again, the majority of respondents (70\%) believed that being aware of other people's cultures makes communication more effective (item 2).

As for item 3, more than $70 \%$ of the respondents (strongly) disagreed that the ultimate goal of English language teaching and learning is to be able to successfully communicate with those who speak it as their first language and live in the environment where the language is dominantly used (e.g., British, American, Australian), leaving around 20\% (strongly) agreeing, and no Uncertain was identified. In line with the responses to item 3 , half of the respondents disagreed with putting emphasis on native speakers' cultures when teaching English (item 4), while 30\% of respondents to some degree agreed with the idea. Up until this point, it is interesting to learn that teachers tend to be aware of the importance of culture, and that the native norm has not generally been treated as the only objective.

When it comes to the presentation of a wide range of contexts (item 5), all of the respondents had no objection. This implies that they realize the benefits of exploring various cultures when learning English. In the case of the inclusion of Thai contexts in teaching materials (item 6), similar to the responses to item 5, none of the respondents disagreed, with an overwhelming majority strongly agreeing (83.3\%). This may have been because they found presenting English through students' contexts can facilitate students' self-expression in English, because over $80 \%$ of the respondents 
reacted positively to item 7 , confirming that while culturally diversifying teaching material is crucial, students' identities should not be ignored.

Some multiple-choice questions were also used to gain insight into the teachers' preference of cultural content. Approximately $80 \%$ of the respondents advocate either local culture or a wide variety of international cultures (item 8), while the rest either abide nativism or did not answer. Once asked about the type of cultural content that can spark students' interests (item 9), over $90 \%$ of the respondents believed that either local culture or a wide variety of cultures have such qualities, showing that teachers see the value of local and cultural diversity in teaching materials. Nevertheless, mixed findings can be seen in the responses to the last question concerning cultural presentation in the coursebooks that they were using (item 10), with several positive (53.3\%) and negative responses (33.3\%) identified. The reason behind this may have been the ELT coursebooks varied from school to school, because there are a handful of series available on the national market.

Table 6. Responses from the teachers $(\mathrm{n}=30) . \mathrm{SA}=$ Strongly agree; $\mathrm{A}=$ Agree; $\mathrm{D}=$ Disagree; $\mathrm{SD}=$ Strongly disagree; $\mathrm{U}=$ Uncertain; $\mathrm{LC}=$ Local contexts; $\mathrm{NC}=$ Native speakers' contexts; VIC $=$ Various international contexts

\begin{tabular}{|c|c|c|c|c|c|}
\hline Statement & SA & $\mathbf{A}$ & D & SD & $\mathbf{U}$ \\
\hline $\begin{array}{l}\text { 1. It is impossible to teach a foreign language without } \\
\text { teaching culture. }\end{array}$ & $\begin{array}{c}15 \\
(50 \%) \\
\end{array}$ & $\begin{array}{c}9 \\
(30 \%) \\
\end{array}$ & $\begin{array}{c}1 \\
(3.3 \%) \\
\end{array}$ & $\begin{array}{c}0 \\
(0 \%) \\
\end{array}$ & $\begin{array}{c}5 \\
(16.6 \%) \\
\end{array}$ \\
\hline $\begin{array}{l}\text { 2. To effectively communicate with someone in } \\
\text { English, you must be aware of their culture. }\end{array}$ & $\begin{array}{c}7 \\
(23.3 \%)\end{array}$ & $\begin{array}{c}14 \\
(46.6 \%)\end{array}$ & $\begin{array}{c}6 \\
(20 \%)\end{array}$ & $\begin{array}{c}0 \\
(0 \%)\end{array}$ & $\begin{array}{c}3 \\
(10 \%)\end{array}$ \\
\hline $\begin{array}{l}\text { 3. Successful communication with native speakers of } \\
\text { English (e.g., British, American) is the ultimate goal of } \\
\text { English language teaching and learning. }\end{array}$ & $\begin{array}{c}4 \\
(13.3 \%)\end{array}$ & $\begin{array}{c}3 \\
(10 \%)\end{array}$ & $\begin{array}{c}12 \\
(40 \%)\end{array}$ & $\begin{array}{c}11 \\
(36.6 \%)\end{array}$ & $\begin{array}{c}0 \\
(0 \%)\end{array}$ \\
\hline $\begin{array}{l}\text { 4. It is important to prioritize native speakers' contexts } \\
\text { over non-native speakers' contexts when teaching } \\
\text { English. }\end{array}$ & $\begin{array}{c}4 \\
(13.3 \%)\end{array}$ & $\begin{array}{c}5 \\
(16.6 \%)\end{array}$ & $\begin{array}{c}15 \\
(50 \%)\end{array}$ & $\begin{array}{c}6 \\
(20 \%)\end{array}$ & $\begin{array}{c}0 \\
(0 \%)\end{array}$ \\
\hline $\begin{array}{l}\text { 5. It is important for ELT coursebooks to present } \\
\text { English in various contexts. }\end{array}$ & $\begin{array}{c}21 \\
(70 \%)\end{array}$ & $\begin{array}{c}9 \\
(30 \%)\end{array}$ & $\begin{array}{c}0 \\
(0 \%)\end{array}$ & $\begin{array}{c}0 \\
(0 \%)\end{array}$ & $\begin{array}{c}0 \\
(0 \%)\end{array}$ \\
\hline $\begin{array}{l}\text { 6. It is important to present Thai contexts (e.g., cuisine, } \\
\text { festivals, places) in ELT coursebooks. }\end{array}$ & $\begin{array}{c}25 \\
(83.3 \%)\end{array}$ & $\begin{array}{c}5 \\
(16.6 \%)\end{array}$ & $\begin{array}{c}0 \\
(0 \%)\end{array}$ & $\begin{array}{c}0 \\
(0 \%)\end{array}$ & $\begin{array}{c}0 \\
(0 \%)\end{array}$ \\
\hline $\begin{array}{l}\text { 7. Presenting English through students' local contexts } \\
\text { makes them feel more at ease expressing themselves in } \\
\text { English. }\end{array}$ & $\begin{array}{c}11 \\
(36.6 \%)\end{array}$ & $\begin{array}{c}14 \\
(46.6 \%)\end{array}$ & $\begin{array}{l}2 \\
(6.6 \%)\end{array}$ & $\begin{array}{c}0 \\
(0 \%)\end{array}$ & $\begin{array}{c}3 \\
(10 \%)\end{array}$ \\
\hline Question & LC & NC & VIC & $\mathbf{U}$ & \\
\hline $\begin{array}{l}\text { 8. Which of the following is the content you would } \\
\text { present in your instructional materials? }\end{array}$ & $\begin{array}{c}8 \\
(26.6 \%)\end{array}$ & $\begin{array}{c}3 \\
(10 \%)\end{array}$ & $\begin{array}{c}17 \\
(56.6 \%)\end{array}$ & $\begin{array}{c}2 \\
(6.6 \%)\end{array}$ & \\
\hline $\begin{array}{l}\text { 9. Which of the following is the content your students } \\
\text { are likely to find interesting? }\end{array}$ & $\begin{array}{c}10 \\
(33.3 \%)\end{array}$ & $\begin{array}{c}2 \\
(6.6 \%)\end{array}$ & $\begin{array}{c}15 \\
(50 \%)\end{array}$ & $\begin{array}{c}3 \\
(10 \%)\end{array}$ & \\
\hline Question & Yes & No & $\mathbf{U}$ & & \\
\hline $\begin{array}{l}\text { 10. Does the ELT coursebook that you are using meet } \\
\text { your expectations in term of cultural presentation? }\end{array}$ & $\begin{array}{c}10 \\
(33.3 \%)\end{array}$ & $\begin{array}{c}16 \\
(53.3 \%)\end{array}$ & $\begin{array}{c}4 \\
(13.3 \%)\end{array}$ & & \\
\hline
\end{tabular}

5. Conclusion

In response to the stated objectives, the approved secondary school ELT coursebooks were analyzed for cultural presentation, and teachers' attitudes toward cultural content in ELT coursebooks were investigated. The findings in the former suggested that six of the coursebooks analyzed still prioritized native speakers' contexts over non-native speakers', not to mention students' contexts, as the target culture is often presented through visuals and reading texts. Time Zone 1, however, breaks through long-established nativism, culturally diversifying its content, so students can experience English through various contexts. Its characters, for example, are often portrayed as non-native speakers, and international contexts are frequently promoted. Even so, the source culture was almost completely absent from the coursebooks. The absence of students' contexts makes them feel disconnected from the learning process (Sumaryono \& Ortiz, 2004).

The questionnaire findings revealed some interesting points concerning teachers' attitudes toward cultural presentation in ELT materials. An overwhelming majority of respondents are aware of the value and role of culture in language education, and realize its importance in intercultural communication. Most of the respondents did not perceive interaction with native speakers as the ultimate goal of English language teaching and learning, and did not agree on placing native speakers' contexts over non-native speakers' contexts. It appears that their beliefs started to shift away from nativism, even though some still advocate the cultures of native speakers. All of them agreed that teaching materials should convey English through the various contexts in which it is used for communication. They also agreed 
that students' culture should be included in teaching materials. Such finding was supported by responses to the following item (item 7), which suggest that students' culture can facilitate self-expression in English. As for preferences of cultural content, more than $80 \%$ of respondents selected either students' contexts or various international contexts. They also believed that such types of contexts can trigger students' interests. However, more than half of the respondents revealed that the coursebooks that they are using did not meet their expectations in term of cultural presentation.

It is evident that Thai secondary teachers in general are ready to embrace the intercultural aspects of English language education, but the materials currently available for them still could not meet the global demand. In order to connect students to the learning process and spark their interests, ELT coursebooks should present English through a wide variety of contexts, including students' contexts. As suggested by advocates of globalized materials (e.g., Kramsch, 1993; Alptekin, 2002; McKay, 2002; Nault, 2006; Shin et al., 2011), the cultural aspects of ELT materials have to be balanced in the way that their cultural content is diversified and one country's particular culture should not be placed above that of others. Localized and culturally diversified materials should be considered for Thai secondary schools nationwide, as they hold the key to intercultural communication, which has become increasingly important in securing success in today's globalized world.

In closing, this study probes into cultural content in ELT coursebook and teachers' attitude toward cultural presentation in ELT coursebooks. Overall, the ELT coursebooks that have been approved to be used in Thai secondary schools were prevailed by native speakers' contexts. The disproportion of the cultural content leads to the conclusion that the culture of native speakers was generally prioritized over that of non-native speakers. However, the recruited teachers tend to realize the importance of intercultural aspects of ELT and signal a call for the content related to students' contexts and other non-native speakers' contexts.

\section{Limitations and Recommendations for Future Research}

Like any research, this study has some limitations which need to be highlighted. Since the scope of this study is limited to cultural presentation in visuals and reading texts, which are only two of many areas wherein cultural value is embedded, future research should investigate other elements such as recordings and other built-in exercises. The number of questionnaire participants is limited in that only English teachers in secondary schools in Bangkok participated. With English teachers from other provinces participating, the questionnaire findings would be much more conclusive. To yield coverage results of coursebook evaluation research, exploring students' perceptions on cultural content should be considered, as it adds another dimension to the research and provides insight into intercultural awareness among learners.

\section{Acknowledgement}

The success of this study required the kind support and help of many individuals. The researcher thanks Dr. Kriangkrai Vathanalaoha and Dr. Vorakorn Tuvajitt for their insightful guidance and constructive feedback. Deepest gratitude goes to the research participants for sharing their perspective. Thanks are also due to Dr. Rick Levinthal for his assistance with language.

\section{References}

Adaskou, K., Britten, D., \& Fahsi, B. (1990). Design decisions on the cultural content of a secondary English course for Morocco. ELT Journal, 44, 3-10. https://doi.org/10.1093/elt/44.1.3

Alptekin, C. (2002). Towards intercultural communicative competence in ELT. ELT Journal, 56(1), 57-64. https://doi.org/10.1093/elt/56.1.57

Altan, M. Z. (1995). Culture in EFL contexts-classroom and coursebooks. Modern English Teacher, 4(2), 58-60.

Ansary, H., \& Babaii, E. (2002). Universal characteristics of EFL/ESL textbook: A step towards systematic textbook evaluation. The Internet TESL Journal, 8(2), 1-8.

Bardovi-Harlig, K. (1996). Pragmatics and language teaching: Bringing pragmatics and pedagogy together. Pragmatics and Language Learning, 7, 21-39.

Baxter, J. (1980). Interactive listening. In L Smith. (ed.). Readings in English as an international language. Pergamon Press.

Cortazzi, M., \& Jin, L. (1999). Cultural mirrors: Materials and methods in the EFL classroom. In E. Hinkel (Ed.), Culture in second language teaching and learning (pp. 196-219). Cambridge: Cambridge University Press.

Crystal, D. (1992). An encyclopedic dictionary of language and languages. Blackwell Publishers.

Crystal, D. (2003). English as a global language. Cambridge: Cambridge University Press. 
https://doi.org/10.1017/CBO9780511486999.003

Cunningsworth, A. (1995). Choosing your coursebook. Oxford: Heineman.

Education First. (2013). EF EPI: EF English proficiency Index. Retrieved from http://www.ef.sg/_/ /media/efcom/epi/2014/full-reports/ef-epi-2013-report-master-new.pdf

Farzaneh, N., Kohandani, M., \& Nejadansari, D. (2014). A Textbook Evaluation of Socio-Cultural Contexts in Top Notch Series. Procedia-Social and Behavioral Sciences, 98, 472-481. https://doi.org/10.1016/j.sbspro.2014.03.442

Fleiss, J. L. (1981). Statistical methods for rates and proportions ( $2^{\text {nd }}$ ed.). New York: Wiley.

Garinger, D. (2002). Textbook selection for the ESL classroom. Center for Applied Linguistics Digest. Retrieved from http://www.cal.org/resources/Digest/0210 garinger.html.

Gass, S. M., \& Selinker, L. (2008). Second Language Acquisition ( $3^{\text {rd }}$ ed.). London: Routledge.

Goldstain, B. (2008). Working with Images: A Resource Book for the Language Classroom. Cambridge: Cambridge University Press.

Hanashiro, K. (2016). How globalism is represented in English textbooks in Japan. Hawaii Pacific University TESOL. Working Paper Series, 14, 2-13.

Hill, D. A. (2013). The Visual Elements in EFL Coursebooks. In B. Tomlinson (Ed.), Developing materials for language teaching (pp. 157-166). London: Bloomsbury.

İşcan, A., Karagöz, B., \& Konyar M. (2017). Cultural Transfer and Creating Cultural Awareness in Teaching Turkish as A Foreign Language: A Sample from Gaziosmanpaşa University Tömer. Journal of Education and Practice, 8(9), 53-63.

Kachru, B. (1992). The Other Tongue. English Across Cultures (2 ${ }^{\text {nd }}$ ed.). Urbana, IL: University of Illinois Press.

Kaplan, R. B. (1983). Contrastive rhetorics: some implications for the writing process. In A. Freedman et al. (Eds.), Learning to Write: First Language/Second Language (pp.139-61). New York: Longman.

Kaur, A., Young, D., \& Kirkpatrick, R. (2016). English Education Policy in Thailand: Why the Poor Results? In R. Kirkpatrick (Ed.), English Language Education Policy in Asia, Language Policy 11 (pp. 345-361). Switzerland: Springer International Publishing. https://doi.org/10.1007/978-3-319-22464-0_16

Kramsch, C. (1993). Context and culture in language teaching. Oxford: Oxford University Press.

Landis, J. R., \& Koch, G. G. (1977). The Measurement of Observer Agreement for Categorical Data. Biometrics, 33, 159-174. https://doi.org/10.2307/2529310

Matsuda, A. (2003). Incorporating World Englishes in teaching English as an international language. TESOL Quarterly, 37(4), 19-29. https://doi.org/10.2307/3588220

Matsuda, A. (2009). Desirable but not necessary? The place of World Englishes and English as an international language in English teacher preparation programs in Japan. In F. Sharifian (Ed.), English as an International Language: Perspectives and Pedagogical Issues (pp. 169-189). Bristol: Multilingual Matters. https://doi.org/10.21832/9781847691231-012

Matsuda, A. (2012). Teaching materials in EIL. In L. Alsagoff, S.L. Mckay, G. Hu \& W. A. Renandya (Eds.), Principles and practices for teaching English as an international language (pp. 168-185). New York: Routledge. https://doi.org/10.21832/9781847697042

McKay, S. L. (2002). Teaching English as an international language: Rethinking goals and approaches. Oxford: Oxford University Press.

McKay, S. L. (2003). The cultural basis of teaching English as an international language. TESOL Matters, 13(4), 1-4.

Melliti, M. (2013). Global Content in Global Coursebooks: The Way Issues of Inappropriacy, Inclusivity, and Connectedness Are Treated in Headway Intermediate. SAGE Open, 1-12. https://doi.org/10.1177/2158244013507265

Ministry of Education. (2008). The basic education core curriculum B.E. 2551 (A.D. 2008). Retrieved from http://www.ipst.ac.th/index.php/news-and-announcements/49-2010-10-27-03-54-42/887-the-basic-education-corecurriculum-be-2551

Monfared, A., Mozaheb, M. A., \& Shahiditabar, M. (2016) Where the difference lies: Teachers' perceptions toward cultural content of ELT books in three circles of world Englishes. Cogent Education, 3, 1-16. https://doi.org/10.1080/2331186X.2015.1125334 
Nault, D. (2006). Going global: Rethinking culture teaching in ELT contexts. Language, Culture and Curriculum, 19(3), 314-328. https://doi.org/10.1080/07908310608668770

Saengboon, S. (2015). An Exploratory Study of Thai University Students' Understanding of World Englishes. English Language Teaching, 8(11), 131-154. https://doi.org/10.5539/elt.v8n11p131

Sherman, J. E. (2010). Uncovering Cultural Bias in EFL Textbooks. Issues in Applied Linguistics, 18(1), 27-53.

Shin, J., Eslami, Z. R., \& Chen, W. (2011). Presentation of local and international culture in current international English-language teaching textbooks. Language, Culture and Curriculum, 24(3), 253-268. https://doi.org/10.1080/07908318.2011.614694

Siddiqie, S. A. (2011). Intercultural exposure through English language teaching: An analysis of an English language textbook in Bangladesh. Journal of Pan-pacific Association of Applied Linguistics, 15(2), 109-127.

Smith, L. E. (1983). Readings in English as an international language. Pergamon Press

Stern, H. H. (1992). Issues and options in language teaching. London: Oxford University Press.

Sumaryono, K., \& Ortiz, F. W. (2004). Preserving the cultural identity of English language learner. Voices from the middle, 11, 16-19.

Suzuki, A. (2007). English as an International Language: a case study of student teachers' perceptions of English in Japan. Retrieved from e-Theses online service (EThOS), (uk.bl.ethos.509926)

Suzuki, A. (2010). Introducing diversity of English into ELT: student teachers' responses. ELT journal, 65(1), 145-153.

Vettorel, P., \& Lopriore, L. (2013). Is there ELF in ELT course-books? Studies in Second Language Learning and Teaching, 4(3). 483-504. https://doi.org/10.14746/ssllt.2013.3.4.3

Vygotsky, L. S. (1986). Thought and language. Cambridge, MA: MIT Press.

\section{Notes}

Note 1. Mathayom refers to Thai secondary school levels. Lower secondary covers Mathayom 1-3 which are equivalent to grades 7-9. Higher secondary covers Mathayom 4-6 which are equivalent to grades 10-12.

Note 2. Rules of interpretation of $\kappa$ value are as follows:

Landis and Koch (1977) proposed that the value of $.81-1.00$ indicates 'almost perfect', $.61-.80$ 'substantial agreement', $.41-.60$ 'moderate agreement', and $.21-.40$ 'fair agreement'. Fleiss (1981) proposed the following criteria for the interpretation: the value of $<.40$ indicating 'poor', $.40-.59$ 'fair', $.60-.74$ 'good', and $>.75$ 'excellent' agreement.

\section{Copyrights}

Copyright for this article is retained by the author(s), with first publication rights granted to the journal.

This is an open-access article distributed under the terms and conditions of the Creative Commons Attribution license which permits unrestricted use, distribution, and reproduction in any medium, provided the original work is properly cited. 